\title{
Foods Promotion to Children: Understanding the Need of Responsibility in Marketing to Children
}

\author{
Pavleen Kaur \\ Department of Commerce and Business Management, Guru Nanak Dev University, Amritsar, India \\ topavleen@yahoo.co.in
}

\begin{abstract}
Children are bombarded with various forms of promotional activities by marketers of food products. It is known that children lack the necessary ability to understand that marketers direct promotions at them after a rigorous analysis of child psychology. They use simple criteria to evaluate products, get carried away by the use of cartoon characters, beautiful/irregular shapes or premiums offered to them. Therefore, relentless promotion often leads to overconsumption of nutrition poor and high density foods, leading to several health problems in children. Although parents also need to control food intake of their children or the government should intervene to check unethical practices of marketers, yet, their efforts are rendered unsuccessful if foods marketing companies themselves do not exercise self-restraint in marketing unhealthy foods to children and also market these foods 'heavily'. The present paper discusses these issues and seeks to attract interest of academicians, marketers and policy makers in India.
\end{abstract}

\section{Key Words: Foods, children, social responsibility, marketing}

\section{Introduction}

Children across the globe are bombarded with promotions for food items. Marketers use various channels to reach children that include advertising, internet, in-school promotions, viral marketing etc. The appeals used also point to the emotions and hardly any rationality is used while framing promotional messages (Page and Brewster, 2007; Stitt and Kunkel, 2008). Children's beverage and snack food choices are significantly affected by exposure to meticulously crafted promotions. Exposure to TV ads, for example, significantly increases consumption of unhealthy foods (Gorn and Goldberg, 1982) and directly affects children's food knowledge, preferences and behaviour (Hastings et al., 2003). The extent of promotion is also intense as the expenditures on promotions are enormous. Companies heavily use television to air a large number of food ads during children's programs or at times when children watch TV. They follow a multi pronged strategy whereby they use advergaming, or highlight premiums/use cartoon characters/celebrities to market foods. A major concern relates to the nature of foods marketed to children. It is found that the foods primarily targeted at children are nutrient poor or high in fat, sugar and salt (HFSS) (Kotz and Story, 1994; Byrd-bredbenner and Grasso, 1999; Arnas, 2006; Kelly et al., 2007; Morgan et al., 2008; Stitt and Kunkel, 2008). A report prepared for WHO (2010), points out that: Today's food environment is quite different to that experienced by previous generations. Globally, an extensive variety of food and drink products are now available in most markets, offering palatability, convenience and novelty. But at the same time, the wide availability and heavy marketing of many of these products, and especially those with a high content of fat, sugar or salt, challenge efforts to eat healthily and maintain healthy weight, particularly in children.

Adoption of these diets is leading to increased prevalence of obesity and other health related disorders in children. Obesity is a serious threat to children's health as it often leads to increased incidence of heart diseases, stroke, Type II diabetes, and poor oral health in children. Effects of food promotion are well researched and date back to 1970's in UK, USA, and Europe (for example, Atkin, 1978, Grossbart and Crosby, 1984). Recently, systematic reviews have been commissioned by international bodies like WHO, OFCOM, FAO etc. that have looked into the effect of food promotion on children. Such initiatives have been taken for obesity has reached alarming levels in the developed countries. It is also rapidly rising in developing countries like India (BBC, 2000; Kapil et al., 2002; Yach et al., 2006; Sharma et al., 2007; Consumers International, 2008). It is pertinent to note here that children (young ones particularly) are naïve consumers and lack competence to understand the psychological gimmicks used by marketers to tap them. They do not have the required cognitive ability to understand the purpose and intent of marketers. Younger kids, particularly, use few dimensions to compare and evaluate brands (Capon and Kuhn, 1980; Bahn, 1986). Children also tend to rely on dominant perceptual features (vs. functional features) of products in gathering information and making choices. They tend to rely on pre-established 
preferences based more often on premium incentives offered on a purchase than the nutritional features of a product (Atkin, 1978).

\section{Food Marketing Tactics used to reach Children}

Based on the understanding of child psychology, marketers devise ad messages and promotional framework deploying emotive appeals, generally. These foods are advertised to children using appeals focussing on fun, fantasy and humour as young children view ads primarily for entertainment. The associations are built with the product/brand only on the basis of liking and trust in the commercial. Children accept the product because their favourite character/personality endorses the product, even when they fail to understand or are given no information about the nutritional quality of advertised product. Marketers rarely focus on nutritional appeals to promote these foods. Page and Brewster (2007) analysed 147 food commercials on children's programs to assess promotional strategies and attention elements used in them. It was found that the most frequently used promotional strategies were jingles/slogans, showing children with food, use of product identification characters (also called branded spokes characters), cross selling of toys and being directed to a website. The common attention elements used were showing 'real children', animation, animals with human characteristics, fast cutting scenes, exciting/fast paced music, humour and colour effects. Stitt and Kunkel (2008) also reviewed 557 ads, out of which none was advertised using a healthy product theme or appeal. The foods were commonly associated with fun or happiness. Fast foods were particularly advertised using fun/happiness appeal along with the heaviest use of premium offers or directing to product based websites. For foods which should not be consumed regularly (such as sugar added yoghurts) or were unhealthy (sugared cereals), licensed characters were mostly used to endorse these products targeted to the child.

In a focus group interview with mothers, Roberts (2005) concluded that premiums often led to increased demand for unhealthy foods. The mothers reported that availability of such foods in schools and the pressure to consume these foods along with friends (to be in the group) are also major factors that hinder promotion of healthy eating habits in children. Similarly, Pettigrew and Roberts (2006) found that premiums were highly effective in promoting fast foods to children. The mothers perceived that frequent promotion of premiums (toys) encourages their children to constantly want more toys and make repeated requests for visits to fast food outlets. Children's awareness of toy premiums also initiates negotiations about future restaurant visits. Children choose a food and food outlets only on the basis of premiums associated and are least concerned about the quality/taste of food available. They expressed that they were caught in a dilemma wherein they wanted to please their children by taking them out to eat but not at the expense of their health. The expectations created by ads were often not realised at the fast food outlet and would then result in distressed children. When mothers attempted to provide counterbalancing information related to nutrition and marketing techniques, they were generally unsuccessful. Thus, advertising of toy premiums was perceived to result into suboptimal diets for children, encourage pestering behaviour, fostering materialistic attitudes and other psychological problems in children. Food ads with premium offers and promotional characters were more frequently placed during peak children viewing hours on children popular programs. Also, a majority of these ads used these tools to promote non-core (unhealthy) foods (Kelly et al., 2008).

A report prepared by Consumers International (2008) looked into the techniques used by six MNCsCoca Cola, Kellogg's, KFC, McDonalds, Nestle and PepsiCo-to market their products to children. It was found that the six companies offered a number of globally recognised food products to children below 16 years of age and that the foods were unhealthy and HFSS according to the criteria set by UK Food Standards Agency. It was reported that although all companies pledged to abstain from marketing to children, yet, they actively indulged in marketing to children. Coca Cola adverts were found on TV during times when children watch TV. Like PepsiCo, it was found to use celebrities to endorse its carbonated beverages. Kellogg's was also found to commonly use its own brand cartoon characters in ads for highly sugared products. The TV ads used animation and showed parents and children together enjoying the food. On pack games, collectibles and movie tie-ins were also promoted through adverts. McDonalds was also found to advertise its 'Happy Meals' on children's channels. It was concluded that advertising of unhealthy foods to children was widespread in Asia Pacific. The promotion of food to children was found to be done through tried and tested traditional marketing approaches, as well as a wide range of highly sophisticated marketing techniques. The report also revealed that the companies did not uniformly follow the labelling measures across countries. It found that Coca Cola did not disclose sugar content in foods marketed in India. 


\section{The Present Situation}

The aforesaid discussion points to the fact that responsibility in marketing to children is largely evaded and the companies seek to earn profits at the cost of children's health. The developed countries have risen to regulate food marketing to children. They have mounted pressure on the industry to either opt for self regulation or face statutory regulation (or complete ban on advertising) by the government. Companies then decided to go for self regulation as it is less stringent, more flexible and leaves with them an opportunity to boost their image as a responsible marketer. However, responsibility in marketing foods to children remains largely ignored or evaded in absence of strict enforcement. The responsibility initiatives, even if they are highlighted by food companies, do not contribute much in actual terms to protecting the health and overall fitness of children (Hawkes, 2005). Therefore, it is pertinent that parents and policy makers learn lessons from the western countries and come forward to realise the threats arising out of rampant marketing of unhealthy foods to their children and ensue responsible actions from marketers.

As pressures are mounting in the developed markets, companies are turning attention to the more lucrative developing countries. It is pertinent to note here that children in developing countries are expected to be more susceptible to the swaying influences of food marketing and promotions owing to lesser exposure to highly sophisticated marketing techniques and less stringent marketing controls. Marketing strategies in lower income countries also are, however, akin to the ones used in affluent markets and largely promote low nutritional foods (Cairns et al., 2009).

\section{Need for Action}

The situation deems attention of all stakeholders-children, parents, nutritionists, NGOs, industry and the government-to avoid a situation of obesity epidemic. Not much research has been conducted in India focussing on the use and impact of promotional strategies and creative elements to market foods to children (Kaur and Singh, 2006). This is the right time to initiate actions to control the situation as obesity and other health related disorders in children have not reached alarming levels. The pace of economic growth in India and changes in lifestyles of people are similar to the ones experienced by other developed nations. Their experiences demonstrate that the food industry has largely evaded responsibility in marketing to children by proposing that an individual is responsible for what he/she eats. It has also been successful in exerting pressure on governments in many countries for several years to not to impose sanctions on it. However, the parents and social activists finally stood up to fight against incessant food marketing and promotions which were causing serious problems to physical health and psychology of children. The companies, then, responded and agreed to follow codes for self regulation (largely to avoid statutory regulation).

So, it is important that food marketing actions directed at children should not be treated as a problem to be resolved at an individual level (by parents or by children singly) in India as well. Parents can contribute by recognising the problems arising out of indiscriminate marketing to children. They can teach their children about healthy eating, provide nutritious diet, and monitor physical activity of their children. But, such actions are difficult to yield results in isolation for promotion activity is ubiquitous and its impact tremendous. Therefore, government should step in to initiate some actions at the public/population level. A complete ban has not been truly successful in protecting interests of children (as reported for Canada) and so does not provide for an optimum solution. Strict regulations are required if marketers do not accept to be ethical and socially responsible. But, to begin with, the government must exert pressure on the industry to at least voluntarily become more responsible in marketing foods to children and abide by the international codes set by International Chamber of Commerce (ICC) or national codes (set by Advertising Standards Council of India and Food Safety and Standards Authority of India). ICC's longstanding view is that "marketing communication is best regulated by effective selfregulation within a legal framework that protects consumers from false and misleading claims. In this way, self-regulation best serves the consumer's interest in receiving truthful and accurate communications. More broadly, marketers should be guided by self-regulatory principles and participate in self-regulatory processes" (http://www.iccindiaonline.org/policy_state/Food.pdf). It is also important to note here that ICC does not deter food marketing companies from using fun and humour in its advertisements. But, it is for the companies to be responsible about use of such appeals and themes in promoting unhealthy foods to children. The problems persist as individual firms are found to pledge against marketing to young children's (below the age of 6 or 8 or 12), to not promote their products in 
schools or avoid internet marketing. These measures are, however, largely evaded (partially implemented). The pledges are made as a global company policy but implemented in selected countries (Consumers International, 2008).

Garde (2008) has also found that the regulations restrict, for example, direct food advertising to children. Therefore, ads seldom make a direct call on children to buy specific products or to use pester power. Advertising is largely indirect and uses techniques such as celebrities, cartoons, or characters to promote foods that bear no relationship sometimes with the food advertised. Considering the sizeable impact of promotions on children's consumption decisions, the marketers have to be self responsible to protect health of children. Being responsible prima facie implies that they promote their unhealthy foods 'less' and thus forego sales and profits. Or, the other way out is that they a) modify the content of foods (reduce fat, sugar and salt) and maintain taste, b) fortify the foods for children with necessary nutrients like calcium and iron, c) reduce use of artificial colours/preservatives that are detrimental to health of children, d) create foods from natural fruits/vegetables that are tasty, full of health as well as funky, e) underscore the need to consume healthy foods such as fruits and vegetables to children, and f) use promotional tools to create awareness amongst children about good eating habits, need for physical exercise and specifically convey to them that these foods are in no way a substitute to the regular meal and must be consumed occasionally. As not much work has already been done in this regard in India, future research must look into the nature and extent of food promotion in India, the promotional tactics deployed by marketers to reach children and their effectiveness, pledges for self-regulation or adherence to self regulatory codes developed by marketers and finally the actual implementation of self regulation by marketers that can make them truly socially responsible.

\section{References:}

Arnas, Y. A. (2006). The effects of television food advertisement on children's food purchasing requests. Paediatrics International, 48: 138-45.

Atkin, C. (1978). Observation of parent-child interaction in supermarket decision-making. Journal of Marketing, 42: 41-45.

Bahn, K. D. (1986). How and when do brand perceptions and preferences first form? A cognitive developmental investigation. Journal of Consumer Research, 13 (Dec): 382-93.

BBC. (2000). West exports obesity to developing world. BBC News Online, September 26. (Available from: URL: http: //news.bbc.co.uk/1/hi/health/943783.stm.).

Byrd-Bredbenner, C., \& Grasso, D. (1999). Prime-time health: An analysis of health content in television commercials broadcast during programs viewed heavily by children. The International Electronic Journal of Health Education, 2(4): 159-69.

Cairns G., Angus K., \& Hastings G. (2009). The extent, nature, and effects of food promotion to children: A review of the evidence to December 2008, A Report prepared for WHO. (Available from: URL: www.who.int/dietphysicalactivity/Evidence_Update_2009.pdf).

Capon, N. \& Kuhn, D. (1980). A Developmental Study of Consumer Information Processing Strategies. Journal of Consumer Research, 8(Dec): 225-33.

Consumers International (2008). The Junk Food Trap, Marketing unhealthy food to children in Asia Pacific, (Available at: URL: www.consumersinternational.org).

Garde, A. (2008). Food Advertising and Obesity Prevention: What role for the European Union? Journal of Consumer Policy, 31: 25-44.

Gorn, G. J. \& Goldberg, M. E. (1982). Behavioural evidence of the effects of TV food messages on children. Journal of Consumer Research, 9(2): 200-05.

Grossbart, S. L. \& Crosby, L. (1984). Understanding the basis of parental concern and reaction to children's food advertising. Journal of Consumer Research, 48: 79-92.

Hastings, G., Stead, M., McDermott, L., Alasdair, F., MacKintosh, A. M., Rayner, M., Godfrey, C., Caraher, M. and Angus, K. (2003). Review of the research on the effects of food promotion to children, Food Standards Agency. (Available from: URL: http: //www.food.gov.uk/multimedia/pdfs/foodpromotiontochildren1.pdf.).

Hawkes, C. (2005). Self-regulation of food advertising: what it can, could and cannot do to discourage unhealthy eating habits among children. Nutrition Bulletin, 30: 374-82.

Kapil, U., Singh, P., Pathak, P., Dwivedi, S. N. \& Bhasin, S. (2002). Prevalence of obesity among affluent adolescent school children in Delhi, Indian Paediatrics; 39: 449-52.

Kaur, P. \& Singh, .R. (2006). Children in family purchase decision making in India and the west-A review. 
Academy of Marketing Science Review, 8(2): 12-34.

Kelly, B., Hattersley, L., King, L. \& Flood, V. (2008). Persuasive food marketing to children: Use of cartoons and competitions in Australian commercial television advertisements. Health Promotion International, 23(4), 337-44.

Kelly, B., Smith, B., King, L., Flood, V. \& Bauman, A. (2007). Television food advertising to children: The extent and nature of exposure. Public Health Nutrition, 10(11): 1234-40.

Kotz, K. \& Story, M. (1994). Food advertisements during children's Saturday morning television programming: Are they consistent with dietary recommendations? Journal of American Dietic Association, 94: 1296-1300.

Morgan, M., Fairchild, R., Phillips, A., Stewart, K. \& Hunter, L. (2008). A Content Analysis of Children's Television Advertising: Focus on Food and Oral Health. Public Health Nutrition, 12(6): 748-55.

Morley, B., Chapman, K., Mehta, K., King, L., Swinburn, B. \& Wakefield, M. (2008). Parental awareness and attitudes about food advertising to children on Australian television. Australian and New Zealand Journal of Public Health, 32(4): 341-47.

Page, R. M. \& Brewster, A. (2007). Frequency of promotional strategies and attention elements in children's food commercials during children's programming blocks on us broadcast networks. Young Consumers, 8(3): 184-196.

Pettigrew, S. \& Roberts, M. (2006). Mothers' attitude towards toys as fast food premiums. Young Consumers, 7(4): 60-68.

Roberts, M. (2005). Parenting in an obesogenic environment. Journal of Research for Consumers, 9: 1-11.

Sharma, A., Sharma, K. \& Mathur, K. P. (2007). Growth pattern and prevalence of obesity in affluent schoolchildren of Delhi. Public Health Nutrition, 10(5): 485-91.

Stitt, C. \& Kunkel, D. (2008). Food advertising during children's television programming on broadcast and cable channels. Health Communication, 23: 573-84.

World Health Organisation. (2010). Set of recommendations on the marketing of foods and non-alcoholic beverages to children, (Available from: URL: http://whqlibdoc.who.int/publications/2010/9789241500210_eng.pdf.)

World Health Organization. (2000). Turning the tide of malnutrition: responding to the challenge of the 21st century, WHO/NHD/00.7. Geneva, Switzerland.

Yach, D., Stuckler, D. \& Brownell, K. D. (2006). Epidemiologic and economic consequences of the global epidemics of obesity and diabetes. Natural Medicine, 12: 62-66. 